\title{
Estimates of crossbreeding parameters in a multibreed beef cattle crossbreeding project
}

\author{
H. Skrypzeck ${ }^{1}$, S.J. Schoeman ${ }^{1 \#}$, G.F. Jordaan ${ }^{1}$ and F.W.C. Neser ${ }^{2}$ \\ ${ }^{1}$ Department of Animal Sciences, University of Stellenbosch, Private Bag X1, Matieland, 7602, South Africa \\ ${ }^{2}$ Department of Animal Science, University of the Orange Free State, P.O. Box 339, Bloemfontein, 9300, South Africa
}

\begin{abstract}
Data from purebred and crossbred cattle, consisting of the Afrikaner (A), Simmentaler (S) and Hereford (H) breeds managed in a relatively intensive but high stocking rate environment, were analysed to estimate breed direct effects, individual heterotic effects, breed maternal and maternal heterotic effects for birth weight (BW) and weaning weight (WW). Simmentaler breed direct effects, expressed as deviation from the general mean, were positive (P $\leq 0.01)$ for both traits. Hereford and Afrikaner breed direct effects were negative $(\mathrm{P} \leq 0.01)$ for both traits while the Afrikaner breed direct effects exceeded those of the Hereford. Afrikaner direct maternal effects were positive (P $\leq 0.01)$ for both traits. The Hereford direct maternal effect was negative $(\mathrm{P} \leq 0.05)(-2.9 \%)$ for WW. Simmentaler maternal effect was negative $(\mathrm{P} \leq 0.01)$ for $\mathrm{BW}$ but non-significant $(\mathrm{P} \geq 0.05)$ for WW. Individual heterotic effects for BW were significant $(\mathrm{P} \leq 0.01)$ in $\mathrm{H} \times \mathrm{S}(3.5 \%)$ and $\mathrm{S} \times \mathrm{A}(11.0 \%)$ only. Individual heterotic effects were positive $(\mathrm{P} \leq 0.01)$ for WW, with that of the $\mathrm{H} \times \mathrm{A}(9.8 \%)$ and $\mathrm{S} \times \mathrm{A}(6.7 \%)$ crosses exceeding the $\mathrm{S} \times \mathrm{H}(3.1 \%)$ cross. Maternal heterotic effects were non-significant $(\mathrm{P} \geq 0.05)$ for both $\mathrm{BW}$ and WW .
\end{abstract}

Keywords: Beef cattle, crossbreeding, direct additive, direct maternal, heterosis

\#Author to whom correspondence should be addressed; e-mail: sjsc@land.sun.ac.za

\section{Introduction}

Production efficiency is of vital importance in weaner production systems, since the dam consumes approximately $94 \%$ of the total digestible nutrients of the dam/calf unit until weaning. Even if the calf is marketed after feedlot finishing, the dam still consumes up to $72 \%$ of the total digestible nutrients of the dam/calf unit (Van der Westhuizen \& Matjuda, 1999).

In cattle production systems crossbreeding can be used to generate heterosis and to make use of differences between breeds to optimise average genetic merit of performance traits for adaptability to the various climatic and nutritive environments (Gregory \& Cundiff, 1980; Koch et al., 1985). Since mating systems may vary according to the importance of the kinds of gene action (additive or non-additive) affecting economically important traits, genetic manipulation would be more precise if the proportion of the genetic variance that is attributable to additive and nonadditive gene action were known. In addition, knowledge of the maternal contribution to the performance of the offspring is also necessary in planning a sound crossbreeding programme (Dillard et al., 1980). The cumulative advantage of employing these effects can be substantial when crossing genetically diverse breeds. Studies from Gregory \& Cundiff (1980) showed that the cumulative effect of heterosis on traits that contribute to weight of calf weaned per cow exposed to breeding was $23.3 \%$ for crosses among breeds of Bos taurus cattle and $50 \%$ or more for crosses between Bos taurus and Bos indicus breeds. Results also showed that $60 \%$ or more of the observed cumulative heterosis was the result of heterosis effects on maternal characteristics.

Birth weight and weaning weight are important traits in weaner production systems. Accurate estimation of parameters influencing these traits in a variety of environmental conditions is needed to establish crossbreeding systems aimed at maximizing weaner output, since breed additive effects, breed maternal effects, individual heterotic effects and maternal heterotic effects vary with the environmental level (Barlow, 1981), suggesting crossbreeding effect $x$ environment interactions. Generally, the level of heterosis is higher under poor environmental conditions than under good environmental conditions, making crossbreeding the obvious breeding practice under unfavourable conditions. Consequently, the relative importance of these effects should be assessed in a variety of environments. The objective of this study was to determine the contributions of breed additive effects, breed maternal effects, individual heterotic effects and maternal heterotic effects on birth weight (BW) and weaning weight (WW) of the Afrikaner, Hereford and Simmentaler breeds in an intensive environment under high stocking rates. 


\section{Material and Methods}

Data were derived from the farms of the Johannesburg Metropolitan Council which are situated in the Gauteng Province of South Africa. The Johannesburg municipal beef cattle enterprise consists of two farms; namely the Northern farm and the Olifantsvlei farm. These farms form part of the waste water management scheme of the Greater Johannesburg Metropolitan Council. The beef herd is raised on a limited pasture intake system using irrigated annual and perennial rye grass (Lolium spp.) pastures supplemented with Eragrostis curvula hay, maize meal, mavovo (distillers grain) and silages (maize, sorghum and grass) when necessary. Management, replacement and selection procedures of the herd were described in more detail by Paterson (1978, 1981), Paterson et al. (1980) and MacGregor (1997).

After editing, the data consisted of 5923 BW and WW records collected from 1968 to 1982. The three breeds of cattle, viz. Afrikaner (A), Hereford (H) and Simmentaler (S) were mated to produce 25 different breed groups of calves - two purebred and 23 crossbred groups (Table 1). Hereford and Simmentaler sires were initially mated to Afrikaner dams, Simmentaler sires were mated to Hereford dams, and Hereford sires were mated to Simmentaler dams to produce the $\mathrm{F}_{1}$ calves. A small number of calves of $\mathrm{S} \times(1 / 8 \mathrm{H} 7 / 8 \mathrm{~S}), \mathrm{S} \times(1 / 16 \mathrm{~A} 1 / 16 \mathrm{H} 7 / 8 \mathrm{~S})$ and $\mathrm{S} \times(1 / 8 \mathrm{~A}$ $7 / 8 \mathrm{~S}$ ) crosses (i.e. 93\% Simmentaler) were considered as purebred Simmentalers ( $\mathrm{S} \times \mathrm{S}$ ) and were pooled with the purebred Simmentalers. Likewise, a few calves of $\mathrm{H} \times(1 / 8 \mathrm{~A} 7 / 8 \mathrm{H}), \mathrm{H} \times(1 / 16 \mathrm{~A} 1 / 16 \mathrm{~S} 7 / 8 \mathrm{H})$ and $\mathrm{H} \times(1 / 8 \mathrm{~S} 7 / 8 \mathrm{H})$ crosses (i.e. 93\% Hereford) were considered as purebred Herefords $(\mathrm{H} \mathrm{x} \mathrm{H})$ and were pooled with the purebred Herefords. Afrikaner purebred matings were not carried out and such data was therefore not available in this study. The individual number of Hereford sires used was 29 with an average of 66 calves per sire that varied from 2 to 253 per sire. The number of Simmentaler sires used was 18 with an average of 239 calves per sire that varied from 3 to 620 per sire. The number of dams used was 2348 with an average of 6 calves per dam that varied from 1 to 11 calves. The number of calves born by year for each breed group is presented in Table 1. During editing, records of calves without birth dates or birth or weaning weights were omitted as well as those born "out of season" and with unidentified parents. Dam ages ranged from 2 to 16 years. Data from both farms was already pre-adjusted for dam age and weaning age of the calf. Therefore, dam age and weaning age of the calf were not included in both the initial and operational models. Fixed effects included in the models and means for BW and WW are presented in Table 2.

All matings were planned and artificial insemination (using the same sires across the two farms) was used throughout the cattle herd. Heifer calves were inseminated to calve for the first time at approximately two years of age. The majority of calves were born in winter (June to September), while the rest were born during December through March. Season of birth was thus recorded as either "summer born" or "winter born". Calves were weighed after birth and at weaning at approximately 210 days of age.

The General Linear Models procedure (SAS, 1993) was used in an initial analysis of the data. All main effects and all possible first-order interactions were included in the initial models. These models were then fitted according to a step-down procedure in which main effects and first-order interactions not making a significant $(\mathrm{P} \leq$ 0.05) contribution to the total variance were omitted in subsequent analyses. Farm and first-order interactions between year $\mathrm{x}$ farm and year $\mathrm{x}$ genotype were either non-significant or made a minor contribution to the total variance and were thus not included in the final model. The final reduced model for estimating least-squares means (LS means) with standard errors for BW and WW, respectively, was:

$$
\mathrm{Y}_{\mathrm{ijk} \mathrm{l}}=\mu+\mathrm{T}_{\mathrm{i}}+\mathrm{C}_{\mathrm{j}}+\mathrm{S}_{\mathrm{k}}+\mathrm{D}_{\mathrm{l}}+\mathrm{e}_{\mathrm{ijkl}}
$$

where $\quad \mu=$ least-squares means

$\mathrm{T}_{\mathrm{i}}=$ the effect owing to year (15 levels)

$\mathrm{C}_{\mathrm{j}}=$ effect owing to breed group (25 levels)

$\mathrm{S}_{\mathrm{k}}=$ effect owing to the sex of the calf (2 levels)

$\mathrm{D}_{1}=$ effect of season of birth within year (2 levels)

$\mathrm{e}_{\mathrm{ijk} \mathrm{l}}=$ random error.

The LS means and standard errors obtained from the SAS (1993) analysis were subsequently used to estimate the crossbreeding effects, using the CBE3 package of Wolf (1996) and fitting Kinghorn's Model 7 (Kinghorn 1987; Wolf et al., 1995), for BW and WW, respectively. This model provides a large variety of options to choose from in estimating crossbreeding effects. The following individual genetic crossbreeding effects were chosen: additive effects, dominance effects, additive maternal effects and maternal dominance effects. 
The model was:

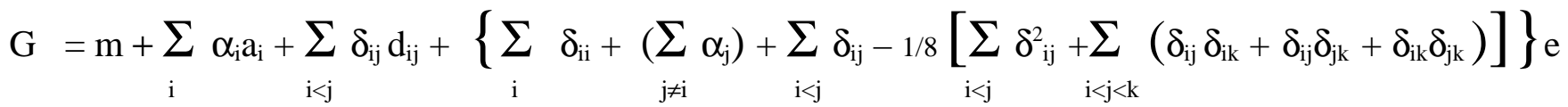

$$
\begin{aligned}
& \mathrm{G}=\text { predicted value of the genetic group } \mathrm{G} \text { under consideration } \\
& \mathrm{m} \quad=\text { general mean } \\
& \alpha_{\mathrm{i},} \alpha_{\mathrm{j}} \quad=\text { proportion of genes from the } \mathrm{i}^{\text {th }} \text { and } \mathrm{j}^{\text {th }} \text { source population in the given genetic group } \\
& \mathrm{a}_{\mathrm{i}} \quad=\text { additive effect of the } \mathrm{i}^{\text {th }} \text { source population } \\
& \delta_{\mathrm{ij},}, \delta_{\mathrm{ik},} \delta_{\mathrm{jk}}=\text { probability that at a randomly chosen locus of a randomly chosen individual of the given genetic } \\
& \text { group, one allele is from the } \mathrm{i}^{\text {th }} \text { and the other allele from the } \mathrm{j}^{\text {th }} \text { source population, one allele is } \\
& \text { from the } \mathrm{i}^{\text {th }} \text { and the other allele from the } \mathrm{k}^{\text {th }} \text { source population, one allele is from the } \mathrm{j}^{\text {th }} \text { and the } \\
& \text { other allele from the } \mathrm{k}^{\text {th }} \text { source population } \\
& \delta_{\mathrm{ii}} \quad=\text { probability that at a randomly chosen locus of a randomly chosen individual of the given genetic } \\
& \text { group both alleles are from the same source population } \\
& \mathrm{d}_{\mathrm{ij}} \quad=\text { dominance effect of the combination of the } \mathrm{i}^{\text {th }} \text { and } \mathrm{j}^{\text {th }} \text { source populations } \\
& \mathrm{e} \quad=\text { epistatic effect (not estimated in this study). }
\end{aligned}
$$

\begin{tabular}{|c|c|c|c|c|c|c|c|c|c|c|c|c|c|c|c|c|}
\hline Breed group ${ }^{1}$ & 1968 & 1969 & 1970 & 1971 & 1972 & 1973 & 1974 & 1975 & 1976 & 1977 & 1978 & 1979 & 1980 & 1981 & 1982 & Total \\
\hline \multicolumn{17}{|l|}{ Pure breeds } \\
\hline$\overline{\mathrm{H} \times \mathrm{H}}$ & 19 & 17 & 43 & 53 & 45 & 38 & 60 & 52 & 37 & 29 & 17 & 24 & 31 & 11 & 2 & 478 \\
\hline$S \times S$ & & & & & & & & 1 & 3 & 4 & 2 & 7 & 10 & 5 & & 32 \\
\hline \multicolumn{17}{|l|}{$\underline{F}_{1}$} \\
\hline $\bar{S} \times A$ & 86 & 60 & 44 & 34 & 31 & 32 & 13 & & & & & & & & & 300 \\
\hline $\mathrm{S} \times \mathrm{H}$ & 125 & 119 & 72 & 50 & 40 & 38 & 2 & & 1 & & & 3 & & & & 450 \\
\hline $\mathrm{H} \times \mathrm{A}$ & 22 & 1 & 15 & 11 & 3 & 8 & 3 & & & & & & & & & 63 \\
\hline $\mathrm{H} \times \mathrm{S}$ & & & & & & & & & 2 & 2 & 2 & 3 & 14 & 1 & 9 & 33 \\
\hline \multicolumn{17}{|l|}{$\frac{\text { Two-breed }}{\text { backcrosses }}$} \\
\hline$\overline{\mathrm{H} \times(1 / 2 \mathrm{~A} 1 / 2 \mathrm{H})}$ & 186 & 21 & 23 & 16 & 10 & 16 & 14 & 8 & 3 & 3 & & & & & & 300 \\
\hline $\mathrm{H} \times(1 / 2 \mathrm{H} 1 / 2 \mathrm{~S})$ & 1 & 2 & 9 & 12 & 17 & 22 & 12 & 14 & 14 & 12 & 8 & 7 & 6 & 5 & & 141 \\
\hline $\mathrm{S} \times(1 / 2 \mathrm{~A} 1 / 2 \mathrm{~S})$ & & 1 & 15 & 33 & 15 & 19 & 24 & 14 & 11 & 7 & 7 & 3 & 1 & & & 150 \\
\hline $\mathrm{S} \times(1 / 2 \mathrm{H} 1 / 2 \mathrm{~S})$ & 1 & 3 & 14 & 46 & 24 & 42 & 29 & 22 & 18 & 10 & 5 & 3 & 3 & 1 & & 221 \\
\hline $\mathrm{H} \times(1 / 4 \mathrm{~A} 3 / 4 \mathrm{H})$ & & & 1 & 3 & 1 & 3 & 10 & 9 & 11 & 5 & 4 & 5 & 3 & 1 & & 56 \\
\hline $\mathrm{H} \times(1 / 4 \mathrm{~S} 3 / 4 \mathrm{H})$ & & & & & & & 2 & 4 & 5 & 4 & & 5 & 5 & 1 & & 26 \\
\hline$S \times(1 / 4 \mathrm{~A} 3 / 4 \mathrm{~S})$ & & & & & & 2 & 2 & 4 & 4 & 6 & 3 & 3 & 5 & 2 & & 31 \\
\hline $\mathrm{S} \times(1 / 4 \mathrm{H} 3 / 4 \mathrm{~S})$ & & & & & 2 & 5 & 3 & 6 & 9 & 15 & 12 & 11 & 8 & 4 & & 75 \\
\hline $\mathrm{H} \times(1 / 4 \mathrm{H} 3 / 4 \mathrm{~S})$ & & & & & & 5 & 6 & 11 & 8 & 6 & 4 & 4 & 5 & 3 & 1 & 53 \\
\hline \multicolumn{17}{|l|}{ Three-breed crosses } \\
\hline$\overline{\mathrm{H} \times(1 / 2 \mathrm{~A} 1 / 2 \mathrm{~S})}$ & 4 & 6 & 23 & 12 & 14 & 20 & 4 & 5 & & 3 & 1 & 3 & & & & 95 \\
\hline $\mathrm{S} \times(1 / 2 \mathrm{~A} 1 / 2 \mathrm{H})$ & 311 & 297 & 308 & 223 & 203 & 156 & 91 & 52 & 30 & 16 & 12 & 2 & 1 & & & 1702 \\
\hline $\mathrm{H} \times(1 / 4 \mathrm{~A} 3 / 4 \mathrm{~S})$ & & & & & & 2 & 2 & 2 & 5 & 4 & 3 & 5 & 8 & & 2 & 33 \\
\hline $\mathrm{S} \times(1 / 4 \mathrm{~A} 3 / 4 \mathrm{H})$ & & & 1 & 24 & 15 & 15 & 2 & 2 & 2 & 1 & 1 & & 1 & & & 64 \\
\hline $\mathrm{S} \times(1 / 4 \mathrm{~A} 1 / 2 \mathrm{H} 1 / 4 \mathrm{~S})$ & & & & 4 & 2 & 4 & 2 & 3 & 2 & 1 & 1 & 2 & & & & 21 \\
\hline $\mathrm{S} \times(1 / 4 \mathrm{~A} 1 / 4 \mathrm{H} 1 / 2 \mathrm{~S})$ & & & 25 & 86 & 65 & 103 & 116 & 124 & 130 & 112 & 41 & 36 & 28 & 16 & & 882 \\
\hline $\mathrm{S} \times(1 / 8 \mathrm{~A} 1 / 8 \mathrm{H} 3 / 4 \mathrm{~S})$ & & & & & & 3 & 7 & 10 & 23 & 31 & 21 & 24 & 14 & 11 & & 144 \\
\hline $\mathrm{H} \times(1 / 8 \mathrm{~A} 5 / 8 \mathrm{H} 1 / 4 \mathrm{~S})$ & & & & & 4 & 1 & & 2 & 9 & 7 & 9 & 16 & 7 & 4 & 1 & 60 \\
\hline $\mathrm{H} \times(1 / 8 \mathrm{~A} 1 / 8 \mathrm{H} 3 / 4 \mathrm{~S})$ & & & & & 1 & 15 & 8 & 20 & 21 & 24 & 21 & 38 & 47 & 15 & 11 & 221 \\
\hline \multirow[t]{2}{*}{$\mathrm{H} \times(1 / 4 \mathrm{~A} 1 / 4 \mathrm{H} 1 / 2 \mathrm{~S})$} & & & 35 & 21 & 29 & 76 & 27 & 49 & 15 & 16 & 9 & 11 & 3 & 1 & & 292 \\
\hline & 755 & 527 & 628 & 628 & 521 & 625 & 439 & 414 & 363 & 318 & 183 & 215 & 200 & 81 & 26 & 5923 \\
\hline
\end{tabular}

Table 1 Number of calves born by year for each breed group 


\section{Results and Discussion}

The analysis of variance for the two traits according to the first model is presented in Table 2 .

Table 2 Means and test statistics for BW and WW

\begin{tabular}{lcc}
\hline & \multicolumn{2}{c}{ Traits $(\mathrm{kg})$} \\
\cline { 2 - 3 } & $\mathrm{BW}$ & $\mathrm{WW}$ \\
\hline Years & $33.3^{* * *}$ & $53.0^{* * *}$ \\
Breed group & $17.9 * * *$ & $17.2^{* * *}$ \\
Sex & $384.5^{* * *}$ & $353.8^{* * *}$ \\
Season of birth & $14.9 * * *$ & $89.9 * * *$ \\
Error mean square & 23.7 & 864.1 \\
Mean \pm s.d. & $34.7 \pm 4.86$ & $191.6 \pm 29.39$ \\
$\mathrm{R}^{2}$ model $(\%)$ & 21.9 & 31.4 \\
$* * * \mathrm{P} \leq 0.001$ & &
\end{tabular}

All effects in the model were significant sources of variation. BW and WW were, respectively, $2.5 \mathrm{~kg}$ and $14.4 \mathrm{~kg}$ higher for bull calves than for heifer calves. Sex differences reported by Marlowe \& Gaines (1958), Ellis et al. (1965), Cundiff et al. (1966), Brinks et al. (1972), Smith et al. (1976), Dillard et al. (1980) and Van Zyl et al. (1992) are in general agreement with these results. Breed group effects were also significant $(\mathrm{P} \leq 0.001)$ for both traits considered, accounting for 5.7 and $4.8 \%$ of the variation in BW and WW respectively. Analysing data from a different crossbreeding project also using Afrikaner, Simmentaler and Hereford, Schoeman et al. (1993) found that breed group effects accounted for 17.3 and $39.9 \%$ of the variation in BW and WW, which is considerably higher than in this study. This difference may be environmentally related.

The coefficients of determination $\left(\mathrm{R}^{2}\right)$ for $\mathrm{BW}$ and WW were 21.9 and $31.4 \%$ respectively. In another study Schoeman et al. (1993) reported $\mathrm{R}^{2}$ values of 32.5 and $64.1 \%$ for BW and WW respectively for the models fitted by these authors. This indicates that a large amount of variation was not accounted for by the models fitted in the present study. This may be due to unidentified sources of variation resulting from management practices and between-year consistency in feed availability owing to the irrigated pastures.

LS means for the breed and crossbred groups are presented in Table 3. It should be noted that dummy LS means were allocated to two breed groups. Without these dummy LS means, some crossbreeding effects could not have been estimated. The LS means for BW and WW were calculated as follows. The purebred breed group of Afrikaner was adjusted proportionally from the Hereford and Simmentaler LS means with values which were obtained from the National Beef Cattle Performance and Progeny Testing Scheme (Schoeman, 1996) since there was no information on Afrikaner x Afrikaner matings available. No data on matings between Afrikaner sires and other types of crosses were available either, therefore, the LS means of A x (1/2H 1/2A) for BW and WW were calculated from the mid-parent value adding $8 \%$ (assumed) heterosis (Long, 1980).

$\mathrm{BW}$ was heavier in the $\mathrm{F}_{1}(34.4 \mathrm{~kg})$ than in the other mating types. Likewise, $\mathrm{BW}$ of the $\mathrm{F}_{1}$ was heavier in the Mara crossbreeding project (Schoeman et al., 1993) than the other mating types. The three-breed cross (186.6 kg) performed the best of all mating types and exceeded the purebred means (177 $\mathrm{kg}$ ) by $5.4 \%$ for WW, except the purebred Simmentaler which had the highest WW $(205.4 \mathrm{~kg})$ and exceeded the three-breed cross mean by $10.1 \%$ for WW. The means of $F_{1}$ and two-breed backcrosses for WW were 185.9 and 185.7 respectively.

Differences in breed additive, maternal additive, individual heterotic and maternal heterotic effects are the most important reasons for differences in performances among breed groups (Dillard et al., 1980). The crossbreeding components, obtained from the second model, are presented in Table 4. 
Table 3 Observed LS means ( \pm s.e.) and predicted LS means of BW and WW for breed groups

\begin{tabular}{|c|c|c|c|c|}
\hline \multirow[b]{2}{*}{ Breed group ${ }^{1}$} & \multicolumn{2}{|c|}{$\begin{array}{l}\text { Observed } \\
\text { Traits }(\mathrm{kg})\end{array}$} & \multicolumn{2}{|c|}{$\begin{array}{l}\text { Predicted } \\
\text { Traits }(\mathrm{kg})\end{array}$} \\
\hline & $\mathrm{BW}$ & WW & BW & WW \\
\hline Pure breeds & $31.6^{*}$ & $177.0 *$ & $32.0 *$ & $174.9 *$ \\
\hline$\overline{\mathrm{H} \times \mathrm{H}}$ & $31.9 \pm 0.51$ & $170.3 \pm 3.06$ & 31.8 & 169.1 \\
\hline$A \times A^{2}$ & $29.3 \pm 0.75$ & $155.2 \pm 4.51$ & 29.3 & 155.2 \\
\hline$S \times S$ & $33.7 \pm 0.99$ & $205.4 \pm 5.96$ & 34.5 & 200.3 \\
\hline$\underline{F}_{1}$ & $34.4^{*}$ & $185.9 *$ & $34.2 *$ & $188.1 *$ \\
\hline $\bar{S} \times A$ & $35.7 \pm 0.54$ & $192.2 \pm 3.28$ & 35.6 & 191.1 \\
\hline $\mathrm{S} \times \mathrm{H}$ & $35.8 \pm 0.51$ & $191.7 \pm 3.09$ & 35.2 & 188.6 \\
\hline $\mathrm{H} \times \mathrm{A}$ & $32.4 \pm 0.71$ & $178.3 \pm 4.66$ & 32.6 & 180.4 \\
\hline $\mathrm{H} \times \mathrm{S}$ & $33.7 \pm 1.00$ & $181.4 \pm 6.04$ & 33.4 & 192.2 \\
\hline Two-breed backcrosses & $30.6^{*}$ & $185.7^{*}$ & $33.4 *$ & $185.0^{*}$ \\
\hline$\overline{\mathrm{H} \times(1 / 2 \mathrm{~A} 1 / 2 \mathrm{H})}$ & $32.8 \pm 0.55$ & $180.2 \pm 3.35$ & 32.2 & 175.8 \\
\hline $\mathrm{H} \times(1 / 2 \mathrm{H} 1 / 2 \mathrm{~S})$ & $33.6 \pm 0.61$ & $185.8 \pm 3.70$ & 33.3 & 182.2 \\
\hline $\mathrm{S} \times(1 / 2 \mathrm{~A} 1 / 2 \mathrm{~S})$ & $35.2 \pm 0.61$ & $194.3 \pm 3.67$ & 34.8 & 193.4 \\
\hline $\mathrm{S} \times(1 / 2 \mathrm{H} 1 / 2 \mathrm{~S})$ & $35.7 \pm 0.56$ & $195.5 \pm 3.41$ & 35.6 & 196.0 \\
\hline $\mathrm{A} \times(1 / 2 \mathrm{H} 1 / 2 \mathrm{~A})^{2}$ & $29.9 \pm 0.60$ & $171.6 \pm 3.53$ & 29.9 & 171.6 \\
\hline $\mathrm{H} \times(1 / 4 \mathrm{~A} 3 / 4 \mathrm{H})$ & $31.6 \pm 0.80$ & $166.3 \pm 4.81$ & 32.0 & 172.5 \\
\hline $\mathrm{H} \times(1 / 4 \mathrm{~S} 3 / 4 \mathrm{H})$ & $32.6 \pm 1.07$ & $173.1 \pm 6.44$ & 32.6 & 175.7 \\
\hline $\mathrm{S} \times(1 / 4 \mathrm{~A} 3 / 4 \mathrm{~S})$ & $34.2 \pm 0.99$ & $194.3 \pm 5.97$ & 34.7 & 196.9 \\
\hline $\mathrm{S} \times(1 / 4 \mathrm{H} 3 / 4 \mathrm{~S})$ & $35.8 \pm 0.73$ & $199.9 \pm 4.41$ & 35.1 & 198.1 \\
\hline $\mathrm{H} \times(1 / 4 \mathrm{H} 3 / 4 \mathrm{~S})$ & $33.7 \pm 0.97$ & $196.1 \pm 4.89$ & 33.4 & 187.2 \\
\hline Three-breed crosses & $34.0 *$ & $186.6^{*}$ & $34.1 *$ & $188.7 *$ \\
\hline$\overline{\mathrm{H} \times(1 / 2 \mathrm{~A} 1 / 2 \mathrm{~S})}$ & $32.8 \pm 0.55$ & $185.9 \pm 4.10$ & 32.8 & 184.1 \\
\hline $\mathrm{S} \times(1 / 2 \mathrm{~A} 1 / 2 \mathrm{H})$ & $35.5 \pm 0.48$ & $191.6 \pm 2.88$ & 35.3 & 190.9 \\
\hline $\mathrm{H} \times(1 / 4 \mathrm{~A} 3 / 4 \mathrm{~S})$ & $33.1 \pm 0.81$ & $191.2 \pm 5.83$ & 33.1 & 188.1 \\
\hline $\mathrm{S} \times(1 / 4 \mathrm{~A} 3 / 4 \mathrm{H})$ & $33.1 \pm 0.77$ & $181.3 \pm 4.63$ & 35.3 & 189.7 \\
\hline $\mathrm{S} \times(1 / 4 \mathrm{~A} 1 / 2 \mathrm{H} 1 / 4 \mathrm{~S})$ & $34.9 \pm 1.16$ & $189.2 \pm 7.00$ & 35.5 & 193.4 \\
\hline $\mathrm{S} \times(1 / 4 \mathrm{~A} 1 / 4 \mathrm{H} 1 / 2 \mathrm{~S})$ & $35.1 \pm 0.49$ & $194.2 \pm 2.94$ & 35.2 & 194.7 \\
\hline $\mathrm{S} \times(1 / 8 \mathrm{~A} 1 / 8 \mathrm{H} 3 / 4 \mathrm{~S})$ & $34.6 \pm 0.62$ & $195.4 \pm 3.74$ & 34.9 & 197.5 \\
\hline $\mathrm{H} \times(1 / 8 \mathrm{~A} 5 / 8 \mathrm{H} 1 / 4 \mathrm{~S})$ & $31.8 \pm 0.78$ & $168.7 \pm 4.74$ & 32.7 & 177.3 \\
\hline $\mathrm{H} \times(1 / 8 \mathrm{~A} 1 / 8 \mathrm{H} 3 / 4 \mathrm{~S})$ & $33.3 \pm 0.57$ & $187.4 \pm 3.42$ & 33.2 & 187.8 \\
\hline $\mathrm{H} \times(1 / 4 \mathrm{~A} 1 / 4 \mathrm{H} 1 / 2 \mathrm{~S})$ & $32.6 \pm 0.54$ & $181.0 \pm 3.26$ & 33.0 & 183.1 \\
\hline
\end{tabular}

${ }^{1}$ Breed of sire is identified by first symbol in crosses.; ${ }^{2}$ dummy breed groups; ${ }^{*}$ mean values

The additive contributions for BW were positive for Simmentaler (10.9\%) and negative for both the Hereford $(2.9 \%)$ and the Afrikaner $(8.0 \%)$. These values were all significant $(\mathrm{P}<0.01)$ and the Hereford additive effects exceeded those of the Afrikaner. Investigations of Cunningham \& Magee (1988) showed that the direct additive effect for BW was negative $(-0.04 \mathrm{~kg})$ for the Simmentaler compared to the Hereford breed. Schoeman et al. (1993) also obtained a positive direct additive effect $(0.74 \mathrm{~kg})$ for the Hereford compared to the Afrikaner breed. Simmentalers produced heavier calves than Herefords, and Herefords produced heavier calves than Afrikaners. These results are in accordance with those of Burns et al. (1988), Schoeman et al. (1993) and Schoeman (1996).

The additive contributions for WW were positive for the Simmentaler (12.2\%) and negative for both the Hereford (3.9\%) and the Afrikaner (8.3\%). These values were all significant $(\mathrm{P} \leq 0.01)$ and the Hereford additive effects exceeded those of the Afrikaner. The high direct additive effects of the Simmentaler indicate that using this breed as one parent in a crossbreeding system involving Hereford and Afrikaner will increase both BW and WW.

In the investigation carried out by Schoeman et al. (1993) at the Mara research station, the Hereford's 
additive contribution was small positive (4.1\%) and that of the Simmentaler large positive (21.9\%) when compared to the Afrikaner. MacNeil et al. (1982) also obtained negative estimates of direct breed effects for Hereford (-19.0 $\mathrm{kg}$ ) and Angus $(-12.2 \mathrm{~kg})$, but positive estimates for Charolais $(12.4 \mathrm{~kg})$ and Simmentaler $(14.6 \mathrm{~kg})$. Calves of Simmentalers were heavier at weaning than calves of Herefords, while Herefords produced heavier calves than Afrikaners in this study. These results are in accordance with those of Cunningham \& Magee (1988), Schoeman $(1989,1996)$ and Schoeman et al. (1993). Average weaning weights of Hereford and Simmentaler cattle taking part in the National Beef Cattle Performance Testing Scheme (Schoeman, 1996) were $24.7 \mathrm{~kg}$ (or 14.5\%) and $30.6 \mathrm{~kg}$ (or 14.9\%) heavier, respectively, than the observed LS means of the purebred Hereford and Simmentaler in this herd, possibly indicating that the environment in which the herd is managed is a relatively unfavourable one. In the Vaalhartz crossbreeding project (Els, 1988) the average WW of Simmentaler and Hereford were $15 \mathrm{~kg}$ (or 7.3\%) and $30 \mathrm{~kg}$ (or 17.6\%) heavier, respectively, than in this herd. Likewise, mean WW of both Simmentaler and Hereford were on average $36.5 \mathrm{~kg}$ (or 17.8\%) and $34.6 \mathrm{~kg}$ (or 20.3\%) heavier, respectively, in the Mara crossbreeding project (Schoeman et al., 1993), also supporting this conclusion. The relatively intensive unfavourable environment may be due to high stocking rates in the herd, thus leading to overgrazing and limited feed availability.

The breed maternal effects are the environmental influences the dam has on her offspring's performance, but it depends on the genotype of the dam and it's associated environmental effects (Koch, 1972; Baker, 1980; Schoeman et al., 1993). It therefore quantifies the maternal ability of the dam, which is for WW, mostly a reflection of the dam's milk production. Direct maternal effects were significant in 4 of the 6 estimates obtained (Table 4).

Table 4 Crossbreeding component estimates ( \pm s.d.) for BW and WW

\begin{tabular}{|c|c|c|}
\hline \multirow[b]{2}{*}{ Component } & \multicolumn{2}{|c|}{ Traits (kg) } \\
\hline & BW & WW \\
\hline General mean & $33.20 \pm 0.24 * *$ & $181.08 \pm 0.08 * *$ \\
\hline \multicolumn{3}{|l|}{ Additive genetic } \\
\hline$\overline{\text { Hereford }(\mathrm{H})}$ & $-0.96 \pm 0.29 * *$ & $-7.05 \pm 1.77 * *$ \\
\hline Afrikaner (A) & $-2.65 \pm 0.41 * *$ & $-15.04 \pm 2.46 * *$ \\
\hline Simmentaler (S) & $3.61 \pm 0.32 * *$ & $22.09 \pm 1.99 * *$ \\
\hline \multicolumn{3}{|c|}{ Individual heterosis } \\
\hline $\mathrm{H} \times \mathrm{A}$ & $1.35 \pm 0.72$ & $17.82 \pm 4.48 * *$ \\
\hline $\mathrm{H} \times \mathrm{S}$ & $1.16 \pm 0.45^{* *}$ & $5.65 \pm 2.71 *$ \\
\hline$S \times A$ & $3.62 \pm 0.62 * *$ & $12.07 \pm 3.75^{* *}$ \\
\hline \multicolumn{3}{|l|}{ Direct maternal } \\
\hline Hereford & $-0.35 \pm 0.35$ & $-5.16 \pm 2.17 *$ \\
\hline Afrikaner & $2.75 \pm 0.53 * *$ & $8.44 \pm 3.20 * *$ \\
\hline Simmentaler & $-2.40 \pm 0.38 * *$ & $-3.28 \pm 2.31$ \\
\hline \multicolumn{3}{|l|}{ Maternal heterosis } \\
\hline $\mathrm{H} \times \mathrm{A}$ & $0.40 \pm 0.39$ & $3.75 \pm 2.37$ \\
\hline $\mathrm{H} \times \mathrm{S}$ & $-0.30 \pm 0.45$ & $0.31 \pm 2.74$ \\
\hline$S \times A$ & $-0.51 \pm 0.43$ & $2.06 \pm 2.80$ \\
\hline
\end{tabular}

For BW, the breed maternal effect was positive $(8.3 \%)$ and significant $(\mathrm{P} \leq 0.01)$ for the Afrikaner, but negative $(7.2 \%)$ and significant $(\mathrm{P} \leq 0.01)$ for the Simmentaler. Calving difficulties when crossbreeding with Simmentaler are therefore most likely the result of the positive direct effect on BW.

The high positive Afrikaner maternal direct effect contradicts reports that seem to indicate that Sanga and Zebu type dams restrict the BW of their calves (Roberson et al., 1986; Comerford et al., 1987; Tawonezvi et al., 1988; Scholtz et al., 1990; Van Zyl et al., 1992; Franke, 1994), even when mated to late maturing Bos taurus sires with a positive additive effect on BW (Alenda et al., 1980) by way of a large negative maternal effect (Roberson $e t$ al., 1986).

The direct maternal effect for the Hereford was positive in some investigations (Alenda et al., 1980; Dillard 
et al., 1980; Cunningham \& Magee, 1988; Schoeman et al., 1993; Arthur et al., 1994; Franke, 1994), while it was negative in others (Gregory et al., 1978), depending on the breeds it was compared with. Schoeman et al. (1993) also obtained a negative direct maternal effect for the Simmentaler while Cunningham \& Magee (1988) obtained positive direct maternal effects for the Simmentaler. Schoeman et al. (2000) illustrated that the maternal breeding values for BW increased almost linearly with an increase in Simmentaler proportion in later generations of the same population.

For WW, the direct maternal effect was negative $(2.9 \%)$ and significant $(\mathrm{P} \leq 0.05)$ for the Hereford, and positive $(4.7 \%)$ and significant $(\mathrm{P} \leq 0.05)$ for the Afrikaner. The direct maternal effect for the Simmentaler was nonsignificant $(\mathrm{P} \geq 0.05)$.

The direct maternal effect for the Hereford was positive in some investigations (Dillard et al., 1980; Koch et al., 1985; Cunningham \& Magee, 1988; Arthur et al., 1994), while it was negative in others (Gregory et al., 1978; Alenda et al., 1980; Schoeman et al., 1993; Franke, 1994), depending on the breeds it was compared with. It is also known that the Hereford is a low milk producing breed (Jenkins \& Ferrell, 1992). Meyer (1992) and Schoeman et al. (1993) associated the low WW in Hereford dams to the low milk production of the Hereford dam. Other investigations (Van Zyl, 1990; Schoeman et al., 1993) also suggested that Afrikaner dams were superior in terms of milk production to Hereford dams. Bonsma (1949) reported that where climatic conditions have a restrictive effect upon milk production, the Afrikaner produces more milk than Bos taurus breeds.

Contrary to the results obtained in this study, both Cunningham \& Magee (1988) and Schoeman et al. (1993) obtained high positive direct maternal effects for the Simmentaler. Being a dual-purpose breed it is known that Simmentaler dams are superior in milk production compared to Hereford dams (Cunningham \& Magee, 1988; Jenkins \& Ferrell, 1992; Schoeman et al., 1993). In analysing part of the same dataset, Schoeman et al. (2000) illustrated that the maternal breeding values for WW increased linearly with an increase in Simmentaler proportion in later generations.

Arthur et al. (1994) evaluated Brahman and Hereford cattle and their crosses on high, medium and low quality pastures and found that the Brahman maternal additive effect, compared to the Hereford, was negative on the high and medium quality pastures, and highly positive and significant in the low quality pastures. This clearly illustrated the re-ranking of breeds for crossbreeding parameters in differing environments. Likewise, the positive maternal additive effect of Afrikaner and the non-significant effect of Simmentaler on WW of calves in this study may be an indication of a relatively unfavourable nutritional environment in this herd. High stocking rates with high nutritional requirements of the Simmentaler may partly explain the reason for the high positive maternal effects of the Afrikaner versus the non-significant direct maternal effect of the Simmentaler and the contradiction with other studies (Schoeman et al., 1993). The Afrikaner should therefore be considered as an appropriate dam line for this specific environment in crossbreeding.

Individual heterotic effects for BW were significant $(\mathrm{P} \leq 0.01)$ in $\mathrm{H} \times \mathrm{S}$ and $\mathrm{S} \times \mathrm{A}$ only (Table 4). The individual heterosis contributions for $\mathrm{H} \times \mathrm{S}$ and $\mathrm{S} \times \mathrm{A}$ were 3.5 and 11.0\%, respectively. Schoeman et al. (1993) obtained a larger and significant heterosis component for the $\mathrm{H} \times \mathrm{A}(5.3 \%)$ cross, while in the $\mathrm{H} \times \mathrm{S}(1.6 \%)$ and $\mathrm{S} \times$ A $(0.05 \%)$ crosses it was non-significant. In beef cattle direct heterosis effects generally range from 1 to $11 \%$ for BW, with values for Bos indicus x Bos taurus at the upper end of the scale (Long, 1980; Cundiff et al., 1986; Arthur et al., 1999). The percentage heterosis obtained in this study is thus within the range of reported literature values. In a study of crosses among Angus, Brahman, Charolais and Hereford breeds, Franke (1994) reported that the direct heterotic effect from Brahman combinations for BW increased over other breed combinations.

Individual heterotic effects for WW were all significant $(\mathrm{P} \leq 0.01)$ (Table 4). The heterosis contributions for H x A, H x S, S x A were 9.8, 3.1 and 6.7\%, respectively. The heterotic effects obtained by Schoeman et al. (1993) were also significant $(\mathrm{P} \leq 0.01)$ for all three breed combinations, and were $11.0 \%$ for $\mathrm{H} \times \mathrm{S}, 10.1 \%$ for $\mathrm{H} \times \mathrm{A}$, and only $3.1 \%$ for $\mathrm{S} x \mathrm{~A}$. In beef cattle, direct heterosis effects generally range from 3 to $16 \%$ for WW, with values for Bos indicus x Bos taurus at the upper end of the scale (Long, 1980; Cundiff et al., 1986; Arthur et al., 1999). The percentage heterosis obtained in this study is thus within the range of reported literature values. Large heterotic effects are thought to be due to the extreme diversity in the development of Bos indicus and Bos taurus breeds (Roberson et al., 1986). Franke (1994) reported, from crosses made between Angus, Brahman, Charolais and Hereford breeds, that the direct heterotic effect from Brahman combinations for WW increased over other breed combinations. A comparative study by Hetzel (1988) reported that crosses between indigenous breeds and exotic Bos taurus or Brahman did not improve maternal performance above the most productive indigenous breeds. However, the growth rate of progeny was increased. Thus crossbreeding programmes using the superior indigenous breeds as dams and exotic Bos taurus as terminal sire breeds are recommended where controlled mating is feasible. In this study, the $\mathrm{H} \times \mathrm{A}$ and $\mathrm{S} \times \mathrm{A}$ combinations seem to be more favourable than the $\mathrm{H} \times \mathrm{S}$ combination, supporting 
previous evidence that more heterosis is generated when crossing large exotic sires to indigenous dams.

Maternal heterotic effects refer to the heterosis in a population attributable to using crossbred dams instead of purebred dams (increased milk production, improved prenatal environment and fertility). This effect is probably the result of increased environmental advantage of the progeny from crossbred dams because of the increased milk production and prenatal environment provided by the crossbred cow (McDonald \& Turner, 1972; Sheridan 1980; Schoeman et al., 1993). In most studies these estimates are positive which indicates that calves of crossbred dams have a better maternal environment to express their growth potential (Arthur et al., 1999).

Maternal heterotic effects for BW were non-significant $(\mathrm{P} \geq 0.05)$ for all of the three estimates (Table 4). McDonald \& Turner (1972) reported that non-significant or negative maternal heterosis for BW reflects an advantage of the crossbred dam, especially when mated to sires known to produce large calves at birth. Therefore, crossbred cows in this study did not provide a stronger in utero environment effect to increase the probability of dystocia as it is affected by calf birth weight. Studies of McDonald \& Turner (1972), Dillard et al. (1980), Sacco et al. (1989), Van Zyl (1990) and Arthur et al. (1994,1999) are in general agreement with the existence of nonsignificant maternal heterotic effects for BW. In most investigations (Cundiff et al., 1974; Roberson et al., 1986; Dearborn et al., 1987; Elzo et al., 1990; Schoeman et al., 1993) significant maternal heterotic effects for BW have been reported.

Maternal heterotic effects for WW were non-significant $(\mathrm{P} \geq 0.05)$ for all three estimates (Table 4). These results are in contrast with estimates obtained by Dillard et al. (1980), Peacock et al. (1981), Roberson et al. (1986), Dearborn et al. (1987), Schoeman et al. (1993) and Arthur et al. (1994) who all reported significant maternal heterosis effects for WW. However, non-significant maternal heterosis effects for WW involving crosses between Hereford and Brahman were also reported by Arthur et al. (1999) in a temperate environment. The non-significant values of WW may be also explained by a possible unfavourable environment where the performance of the crossbred dam could not be expressed to its full potential. Lamb et al. (1992) reported that purebred dams require less energy than crossbred cows and thus a reduction in performance (milk production) may be expected when energy availability is limited. According to Schoeman (1999) a high level of nutrition and management is sometimes needed before the higher potential in crossbred cows can be fully utilised.

Investigations of Peacock et al. (1981) showed (although the values obtained were much higher and significant) that the maternal heterotic effect was the largest for Angus-Brahman, intermediate for the CharolaisBrahman and lowest for the Angus-Charolais crosses. It confirms the theoretical expectation of greater heterosis in more genetic diverse breed types (especially for Bos taurus x Bos indicus) (Cundiff et al., 1974; Koger et al., 1975; Moyo et al., 1996). Although not significant, this tendency was also present in this study.

\section{Conclusions}

The means of all crossbred types exceeded those of the purebred means, except the purebred Simmentalers which had the highest WW and thus were the highest weaner producers. Within the crossbred groups, those having high proportions of Simmentaler were also the highest producers. Due to the high positive breed additive contributions for WW of Simmentaler (12.2\%) and the high LS means for WW of $205.4 \mathrm{~kg}$, purebred Simmentaler breeding seems to be the best breeding practice for this environment. The breed maternal effects of the Afrikaner were superior to that of the exotic Bos taurus breeds within this specific environment, suggesting a possible genotype $\mathrm{x}$ environmental interaction when compared to other environments. In this study the $\mathrm{H} \times \mathrm{A}$ and $\mathrm{S} \times \mathrm{A}$ combinations seem to be more favourable than the $\mathrm{H}$ x $\mathrm{S}$ combination, supporting previous evidence that more heterosis is generated when crossing large exotic sires to indigenous dams. It might furthermore be suggested that crossbred dams did not provide the expected maternal superiority, and thus a higher nutritional level and improved management is possibly needed in this herd to utilise the higher potential of crossbred dams and to utilize crossbreeding to its full potential. A re-ranking of crossbred mating types and genotypes versus purebreds might have occurred if composite traits (e.g. fertility, cow efficiency, total weaning weight of calves weaned) had been included in this investigation.

\section{Acknowledgement}

The authors are grateful for the use of the data of the Johannesburg Metropolitan Council. Thanks are in particular due to Roger Wood.

\section{References}

Alenda, R., Martin, M.R., Lasley, J.F. \& Ellersieck, M.R., 1980. Estimation of genetic and maternal effects in crossbred cattle of Angus, Charolais and Hereford parentage. I. Birth and Weaning weights. J. Anim. Sci. 
(C) South African Society of Animal Science

50, 226.

Arthur, P.F., Hearnshaw, H., Kohun, P.J. \& Barlow, R., 1994. Evaluation of Bos indicus and Bos taurus straightbreds and crosses. III Direct and maternal genetic effects on growth traits. Aust. J. Agric. Res. 45, 807.

Arthur, P.F., Hearnshaw, H. \& Stephenson, P.D., 1999. Direct and maternal additive and heterosis effects from crossing Bos indicus and Bos taurus cattle: cow and calf performance in two environments. Livest. Prod. Sci. 57, 231.

Baker, R.L., 1980. The role of maternal effects on the efficiency of selection in beef cattle - a review. Proc. N.Z. Soc. Anim. Prod. 40, 285.

Barlow, R., 1981. Experimental evidence for interaction between heterosis and environment in animals. Anim. Breed. Abstr. 49, 715.

Bonsma, J.C., 1949. Breeding cattle for increased adaptability to tropical and subtropical environments. J. Anim. Sci. 39, 205.

Brinks, J.S., Knapp, B.W., Urick, J.J. \& Pahnish, O.F., 1972. Heterosis in preweaning maternal traits among lines of Hereford cattle. J. Anim. Sci. 34,14.

Burns, B.M., Vercoe, J.E. \& Holmes, C.R., 1988. Productive and adaptive trait differences of Simmental, Hereford and Africander x Hereford cattle. J. Agric. Sci., Camb. 111, 475.

Comerford, J.W., Bertrand, J.K., Benyshek, L.L. \& Johnson, M.H., 1987. Reproductive rates, birth weight, calving ease and 24-h calf survival in a four-bred diallel among Simmental, Limousin, Polled Hereford and Brahman beef cattle. J. Anim. Sci. 64, 65.

Cundiff, L.V, Gregory, K.E., Koch, R.M. \& Dickerson, G.E., 1986. Genetic diversity among cattle breeds and its use to increase beef production efficiency in a temperate environment. Proc. $3^{\text {rd }}$ World Cong. Genet. Appl. Livest. Prod. IX, 271. (Nebraska, USA).

Cundiff, L.V, Gregory, K.E., Schwulst, F.J. \& Koch, R.M., 1974. Effects of heterosis on maternal performance and milk production in Hereford, Angus and Shorthorn cattle. J. Anim. Sci. 38, 728.

Cundiff, L.V., Willham, R.L. \& Pratt, C.A., 1966. Effects of certain factors and their two-way interactions on weaning weight in beef cattle. J. Anim. Sci. 25, 972.

Cunningham, B.E. \& Magee, W.T., 1988. Breed-direct, breed-maternal and non-additive genetic effects for preweaning traits in crossbred calves. Can. J. Anim. Sci. 68, 83.

Dearborn, D.D., Gregory, K.E., Cundiff, L.V. \& Koch, R.M., 1987. Maternal heterosis and grandmaternal effects in beef cattle: Preweaning traits. J. Anim. Sci. 65, 33.

Dillard, E.U., Rodriquez, O. \& Robison, O.W., 1980. Estimation of additive and nonadditive direct and maternal genetic effects from crossbreeding beef cattle. J. Anim. Sci. 50, 653.

Ellis, G.F., Cartwright, T.C. \& Kruse, W.E., 1965. Heterosis for birth weight in Brahman-Hereford crosses. J. Anim. Sci. 24, 93.

Els, D.L., 1988. Kruisteling vir vleisproduksie. PhD. Thesis. University of the Orange Free State, Bloemfontein.

Elzo, M.A., Olson, T.A., Butts, W.T., Koger, M. \& Adams, E.L., 1990. Direct and maternal genetic effects due to the introduction of Bos taurus alleles into Brahman cattle in Florida. II. Preweaning growth traits. J. Anim. Sci. 68, 324.

Franke, D.E., 1994. Genetic effects for beef cattle preweaning traits. Proc. $5^{\text {th }}$ World Cong. Genet. Appl. Livest. Prod. 17, 296. (Guelph, Canada).

Gregory, K.E. \& Cundiff, L.V., 1980. Crossbreeding in beef cattle: Evaluation of systems. J. Anim. Sci. 51, 1224.

Gregory, K.E., Cundiff, L.V., Koch, R.M., Laster, D.B. \& Smith, G.M., 1978. Heterosis and breed maternal and transmitted effects in beef cattle II. Preweaning traits. J. Anim. Sci. 47, 1031.

Hetzel, D.J.S., 1988. Comparative productivity of the Brahman and some indigenous Sanga and Bos indicus breeds of East and Southern Africa. Anim. Breed. Abst. 56, 243.

Jenkins, T.G. \& Ferrell, C.L., 1992. Lactation characteristics of nine breeds of cattle fed various quantities of dietary energy. J. Anim. Sci. 70, 1652.

Kinghorn, B.P., 1987. The Nature of 2-Locus epistatic interactions in animals: Evidence from Sewall Wright's guinea pig data. Theor. Appl. Genet. 73, 595.

Koch, R.M., 1972. The role of maternal effects in animal breeding: VI. Maternal effects in beef cattle. J. Anim. Sci. 35, 1316.

Koch, R.M., Dickerson, G.E., Cundiff, L.V. \& Gregory, K.E., 1985. Heterosis retained in advanced generations of crosses among Angus and Hereford cattle. J. Anim. Sci. 60, 1117. 
(C) South African Society of Animal Science

Koger, M., Peacock, F.M., Kirk, W.G. \& Crockett, J.R., 1975. Heterosis effects on weaning performance of Brahman-Shorthorn calves. J. Anim. Sci. 40, 826.

Lamb, M.A., Tess, M.W. \& Robison, O.W., 1992. Evaluation of mating systems involving five breeds for integrated beef production systems: I. Cow-calf segment. J. Anim. Sci. 70, 689.

Long, C.R., 1980. Crossbreeding for Beef Production: Experimental Results. J. Anim. Sci. 51, 1197.

MacGregor, R.G., 1997. Evaluation of methods of measuring reproduction and production in beef cows. $\mathrm{PhD}$ Thesis. University of Pretoria, South Africa.

MacNeil, M.D., Dinkel, C.A. \& Van Vleck, D.L., 1982. Individual and maternal additive and heterotic effects on 205-day weight in beef cattle. J. Anim. Sci. 54, 951.

Marlowe, T.J. \& Gaines, J.A., 1958. The influence of age, sex and season of birth of calf and age of dam on preweaning growth rate and type score of beef calves. J. Anim. Sci. 17, 706.

McDonald, R.P. \& Turner, J.W., 1972. Estimation of maternal heterosis in preweaning traits of beef cattle. J. Anim. Sci. 35, 1146.

Meyer, K., 1992. Variance components due to direct and maternal effects for growth traits of Australian beef cattle. Livest. Prod. Sci. 31, 179.

Moyo, S., Swanepoel, F.J.C. \& Rege, J.E.O., 1996. Evaluation of indigenous, exotic and crossbred cattle for beef production in a semi-arid environment: Reproduction performance and cow productivity. Proc. Aust. Soc. Anim. Prod. 21, 204. (Brisbane, Queensland).

Paterson, A.G., 1978. Statistical analyses of factors affecting preweaning growth of beef cattle under intensive pasture conditions. M.Sc. (Agric.) Thesis. University of Pretoria, South Africa.

Paterson, A.G., 1981. Factors affecting post-weaning growth and reproduction of crossbred cattle under an intensive production system. D.Sc. (Agric.) Thesis. University of Pretoria, South Africa.

Paterson, A.G., Venter, H.A.W. \& Harwin, G.O., 1980. Pre-weaning growth of British, Bos indicus, Charolais and dual purpose type cattle under intensive pasture conditions. S. Afr. J. Anim. Sci. 10,125.

Peacock, F.M., Koger, M., Olson, T.A. \& Crockett, J.R., 1981. Additive genetic and heterosis effects in crosses among cattle breeds of British, European and Zebu origin. J. Anim. Sci. 52, 1007.

Roberson, R.L., Sanders, J.O. \& Cartwright, T.C., 1986. Direct and maternal genetic effects on preweaning characters of Brahman, Hereford and Brahman-Hereford crossbred cattle. J. Anim. Sci. 63, 438.

Sacco, R.E, Baker, J.F., Cartwright, T.C., Long, C.R. \& Sanders, J.O., 1989. Production characters of straightbred, F1 and F2 cows: Birth and weaning characters of terminal-cross calves. J. Anim. Sci. 67, 1972.

SAS/STAT (Statistical Analysis System), 1993. SAS/STAT User's Guide (Version 6). SAS Institute, Inc., Cary, N.C.

Schoeman, S.J., 1989. Recent research into the production potential of indigenous cattle with special reference to the Sanga. S. Afr. J. Anim. Sci. 19, 55.

Schoeman, S.J., 1996. Characterization of beef cattle breeds by virtue of their performances in the National Beef Cattle Performance and Progeny Testing Scheme. S. Afr. J. Anim. Sci. 26, 15.

Schoeman, S.J., 1999. Crossbreeding in beef cattle. In: Beef breeding in South Africa (Ch. 5). Eds. Scholtz, M.M., Bergh, L. and Bosman, D.J., Agric. Res. Council (Animal Improvement Institute), Irene, p. 43.

Schoeman, S.J., Jordaan, G.F. \& Skrypzeck, H., 2000. The influence of proportion of Simmentaler breeding in a multibreed synthetic beef cattle population on preweaning growth traits. S. Afr. J. Anim. Sci. 30, 98.

Schoeman, S.J., Van Zyl, J.G.E. \& De Wet, R., 1993. Direct and maternal additive and heterotic effects in crossbreeding Hereford, Simmentaler and Afrikaner cattle. S. Afr. J. Anim. Sci. $23,61$.

Scholtz, M. M., Roux, C.Z. \& Lombard, P. E., 1990. Breeding strategies for beef cattle in the subtropics and tropics: Terminal crossbreeding. Proc. $4^{\text {th }}$ Wrld. Congr. Gen. Appl. Livest. Prod. XV, 361. (Edinburg)

Sheridan, A.K., 1981. Crossbreeding and heterosis. Anim. Breed. Abst. 49,131.

Smith, G.M., Laster, D.B. \& Gregory, K.E., 1976. Characterization of biological types of cattle I. Dystocia and Preweaning growth. J. Anim. Sci. 43,27.

Tawonezvi, H.P.R., Ward, H.K., Trail, J.C.M. \& Light, D., 1988. Evaluation of beef breeds for rangeland weaner production in Zimbabwe. 2. Productivity of crossbred cows and heterosis estimates. Anim. Prod. 47, 361.

Van der Westhuizen, J. \& Matjuda, L.E., 1999. Breeding objectives. In: Beef breeding in South Africa (Ch. 3). Eds. Scholtz, M.M., Bergh, L. and Bosman, D.J., Agric. Res. Council (Animal Improvement Institute), Irene, p. 27.

Van Zyl, J.G.E., 1990. Studies on performance and efficiency of pure and crossbred cattle in an arid bushveld environment. PhD. (Agric.) Thesis. University of Pretoria, South Africa. 
(C) South African Society of Animal Science

Van Zyl, J.G.E., Schoeman, S.J. \& Coertze, R.J., 1992. Sire breed and breed genotype of dam effects in crossbreeding beef cattle in the subtropics. I. Birth and weaning mass of calves. S. Afr. J. Anim. Sci. 22, 161.

Wolf, J., 1996. CBE, Version 4.0 (A universal program for estimating crossbreeding effects), User's Manuel for the Software Package. Research Institute of Animal Production, CZ 10400 Praha-Uhrineves, Czech Republic.

Wolf, J., Distl, O., Hyánek, J., Grosshans, T. \& Seeland, G., 1995. Crossbreeding in farm animals. V. Analysis of crossbreeding plans with secondary crossbred generations. J. Anim. Breed. Genet. 112, 81. 